\title{
IMPROVING STUDENTS' READING COMPREHENSION SKILL USING HERRINGBONE TECHNIQUE AT MTS AL-FATAH BADAS
}

\author{
Ary Setya Budhi Ningrum \\ Sekolab Tinggi Agama Islam Negeri Kediri \\ ary_oyesip@yahoo.com \\ Ika Widyawati \\ Sekolab Tinggi Agama Islam Negeri Kediri \\ ikawidyawati61@yaboo.co.id
}

\begin{abstract}
Reading is a factor of great importance in the individual development and the most important activity at school. In MTs Al-Fatah, however, the students' reading comprehension score was still low. To overcome the problem, the herringbone technique was implemented to improve the students' reading comprehension in narrative text. Classroom Action Research (CAR) was carried out in this study. This research consists of two cycles. Each cycle consists of two meetings. In cycle 1, the students' score in reading comprehension has not reached the criteria of success yet. There were only 66, 7\% (8 out of 24 students) who passed the criteria of success. So, the researchers revised the plan and continued to the next cycle. In cycle 2, the average score of students was improving. All of students get good score and none get poor score. To sum up, the herringbone technique applied for the eighth grade of MTs al-Fatah Badas was qualified to be able to improve the students' achievement in reading narrative text.
\end{abstract}

Keywords: Reading Comprehension, Narrative Text, Herringbone Technique

\begin{abstract}
Abstrak
Membaca adalab faktor penentu utama dalam setiap perkembangan individu dan merupakan kegiatan penting di sekolah. Akan tetapi di MTS Al-Fatah, kemampuan membaca pemahaman siswa masih rendah. Untuk mengatasi permasalahan tersebut maka teknik Herringbone diimplementasikan untuk meningkatkan kemampuan membaca pemahaman siswa dalam teks narasi. Desain penelitian ini adalah Penelitian Tindakan Kelas (PTK). Ada 2 siklus dalam penelitian ini dimana tiap siklusnya ada dua pertemuan. Di siklus 1, hasil skor siswa belum mampu mencapai kriteria kesuksesan. Hanya 66, 7\% siswa (8 dari 24 siswa) yang mencapai kriteria kesuksesan. Sebingga peneliti merevisi rencana dan melanjutkan ke siklus berikutnya. Di siklus 2, nilai rata-rata siswa meningkat. Semua siswa mendapatkan nilai bagus dan tidak ada yang mendapatkan nilai jelek. Pendek kata teknik Herringbone teruji mampu meningkatkan kemampuan membaca pemahaman siswa dalam teks narasi.
\end{abstract}

Kata Kunci: Membaca Pemahaman, Teks Narasi, Herringbone Teknik

Permalink/DOI: http://dx.doi.org/10.18326/infsl3.v9i2.397-416 


\section{Introduction}

Reading plays an important role in the individual development and the most important activity for the students. By reading activity we can get more knowledge and much information. For language students, moreover, reading is a good thing to do as it provides opportunities to study language: vocabulary, grammar, punctuation, and the way to construct sentences, paragraphs, and texts at once (Harmer, 1998:68).

Reading is one of the four skills that should be mastered by the students besides the ability to understand spoken English, writing ability and speaking ability. As a matter of fact, comprehending texts is sometimes difficult to be achieved. The readers need more than just recalling information given in a text. To comprehend reading is not easy, especially when readers are dealing with new vocabularies and structures which they have not mastered yet. What teachers usually do in class is leading the students, as readers, to focus on the elements and information in the text.

In teaching reading usually teachers' emphasis of teaching is on the students' mastery to comprehend the content to answer the questions which follow the reading (Kristiyani, 2008). In reading narrative text, usually the emphasis is on the element of the story when asking questions. That is why the students' focus of reading is on the elements of fiction such as who the characters and characterizations are, how the plot is described, what the messages are, etc.

In teaching reading for narrative text, teachers should be able to teach students with various methods. Teacher should make it enjoyable; otherwise, the exercise would not be worth teaching. The students think that reading English is not interesting and bored since they do not know the meaning of the words and may not familiar with the story. The students need an interesting methods so that they feel happy and motivated to read and to comprehend the text given. 
In MTs AL-FATAH Badas, the teacher still teaches using uninteresting method. Based on the preliminary study which was intended to get the real condition about the students' problems in the process of teaching and learning, it was found that the strategy used by the teacher does not attract the students' interest. The teacher teaches reading by just explaning and giving the meaning for each new vocabularies to students. After that, the teacher asks the students to answer the worksheet given. This situation makes students unmotivated to follow the teacher's explanation in class. As a consequence, the students had a poor ability in reading comprehension in narrative text.

In light of this situation, the reseachers proposed the use of grapic organizer to be implemented in teaching reading narrative text. Teaching with graphic organizer is teaching technique to increase students' motivation in learning English. Graphic organizers are important and effective pedagogical tools for organizing content and ideas, and facilitating learner's comprehension of newly acquired information (McKnight, 2010). The one of grapic organizers is Herringbone Technique.

Herringbone Technique is a graphic organizer which represent visual information and concepts in teaching learning process. It is so-called because it resembles a fish skeleton. It is a useful technique for analyzing a single idea or text. Herringbone Technique consists of a short graphic organizer and it is a concrete way of helping English learners to find the comprehensive idea in a paragraph or passage (Thaler, 2008: 88). The students answer the questions listed in the herringbone graphic organizer. This leads to the synthesis of all the information in one newly created sentence, which becomes the main idea statement.

Herringbone Technique helps students understand the connections between supporting details to identify a main idea. It is used for establishing supporting details for a main idea and designed to help students locate the main idea of a selection (McKnight, 2010). In implementing Herringbone technique, having reading a story the students looked for answers to the WH- 
questions: who, what, where, when, why and how (Balajthy and Wade, 2003). The teacher helps the students put the information which they locate on a visual diagram shaped like a fish skeleton. Then a summary is written along the central spine of the diagram. This visual diagram is useful for reviewing information and provides a visual structure for the selection that can be seen at a glance.

Several studies has shown the effectiveness of Herringbone Techniques for teaching reading. A study conducted by Anggraeni (2013) revealed that Herringbone Technique is effective for teaching reading narrative text for the eighth grade students at SMP Negri 1 Grobogan in the academic year of 2012/2013. Another study conducted by Saputra (2012) showed that there was possitive effect of using Herringbone technique toward students' reading comprehension of the tenth grade at SMK Negeri 1 Lubuk Sikaping Sumatra Barat.

Based on the preceding explanation, this study is conducted to improve the students' reading skill of the eighth grade students of MTs AL-FATAH Badas by implementing Herringbone technique. By applying Herringbone technique, it is expected that students' reading skill will improve especially reading comprehension in narrative text.

Narrative is a kind of enjoyable text to read. Gallant (2008) states that narrative tells a story, it may include information that will help the reader understand the characters' feelings. Its form is unique, because authors relate ideas they want to express about how people behave and what they believe. It makes connections to the reader's experiences.

Narrative is one of the genres which are used in competence based curriculum. Genre is kinds of texts in which each of them has a social function, generic structure, and lexicon grammatical features. The social purposes of narrative text are to construct a pattern of events, to amuse or entertain, to deal with the unusual or unexpected, to teach readers that problems should be resolved, and to incorporate generally valued patterns of behavior (Keir, 2009). The purpose of 
narrative is to present a view of the world that entertains or informs the reader or listener. In this research, narrative text means kind of story genre which has social function to amuse, entertain with problematic events which followed the resolution.

There are many type of narrative including 1) humor: a humorous narrative is one that aims to make the audience laugh as part of telling story, 2) romance: a romance narrative typically tells of two levels who overcome difficulties to end up together, 3 ) the diary-novel: this type of narrative has the text presented like diary entry, 4) science fiction: science fiction narrative us a setting involving science and technology, 5) fable: a fiction story meant to teach moral lesson: the characters are usually talking animals, 6) myth: a tradition story of unknown authorship, ostensible with a historical basis, but serving usually to explain some phenomenon of nature, the original of man, or the customer, institutions, religion rites of people: myths usually involve the exploits of gods and heroes, 7) legend: a story handed down for generations among a people and popularly believed to have historical basis, although not verifiable (Anderson et. al, 1997). In this current study the narrative text taught was mostly in the form of myth and legend text types.

\section{Research Method}

The design of this study is Classroom Action Research (CAR). The design of classroom action research is adapted the model proposed by Kemmis \& Mc Taggart cited (1998). The subject of the study was the eighth grade students class A of MTs AL-FATAH Badas in the academic year 2013/2014. It consists of 24 students.

This research began by conducting a preliminary study which was intended to get the real condition about the students' problems in the process of teaching and learning. Based on the observation and interview, it was found that: (1) the strategy implemented by the teacher didn't attract the students' interest; (2) the students were not motivated to follow the teacher's explanation in class; and (3) the students had a poor ability in reading comprehension in narrative text. 
This research was conducted in a form of cycles through some steps: (1) planning action, (2) implementing of action, (3) observing of action, and (4) analysis and reflecting.

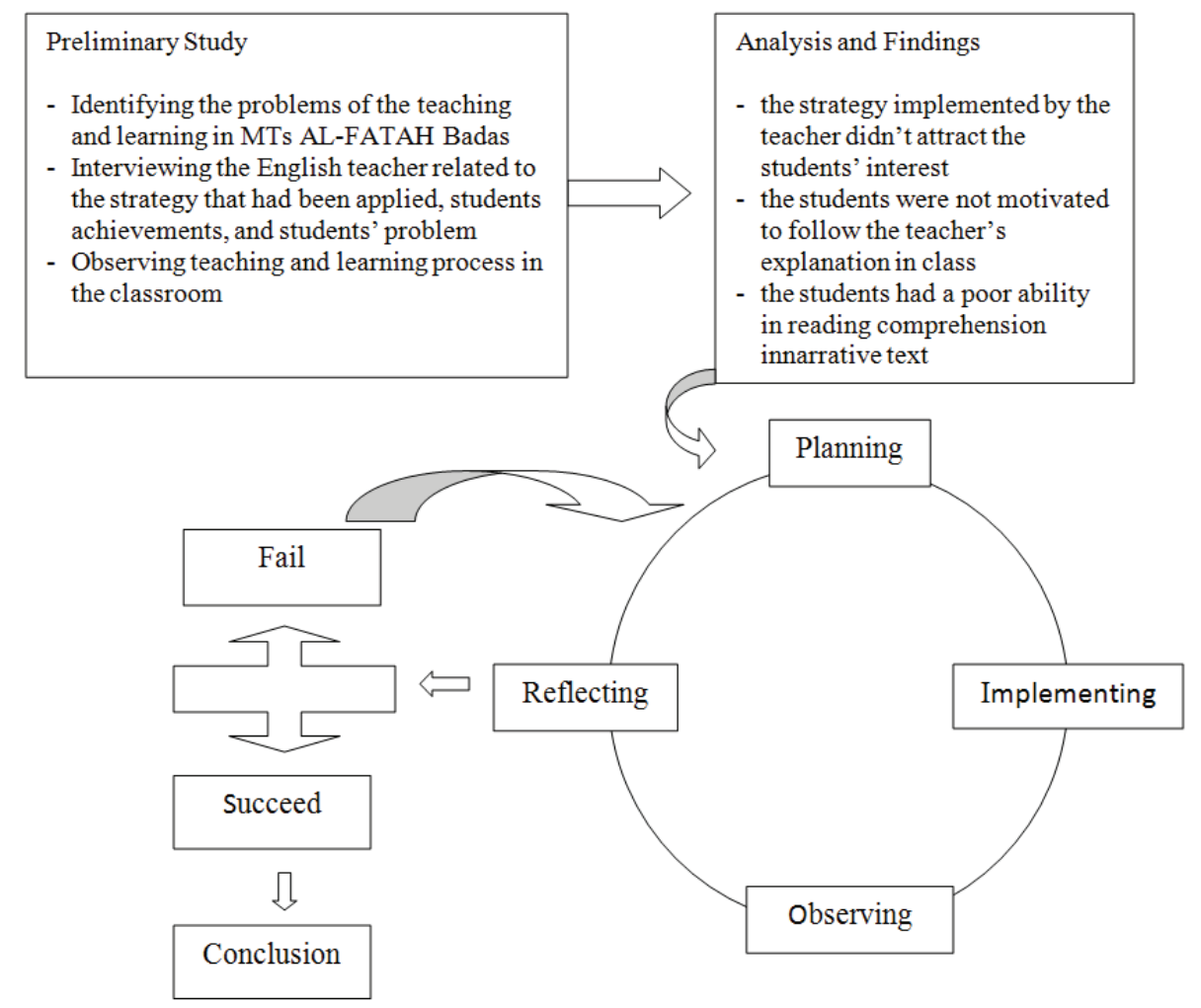

Figure 1.

The Procedures of Classroom Action Research

(Adapted from Kemmis and Mc Taggart cited in Koshy, 2005)

\section{Planning Action}

In the planning step, some instruments were prepared such as the suitable model of lesson plan using herringbone technique, materials and media, and criteria of success.

a. Preparing the Lesson Plan

The lesson plan contains the objectives that were expected to be 
achieved by the students and also the procedure of presenting Herringbone technique in teaching learning process.

In this present study the aim of teaching reading a narrative text is that the students should be able to respond to the meaning and rhetorical steps of a narrative text. Responding to the meaning means that they should be able to determine the main ideas, general ideas, and the content of the text. Meanwhile, responding rhetorical steps means that the students should be able to determine all the language features of narrative text.

The steps of teaching learning designed was adapted from Edwards (2003:32) as follows:

1. Select reading material at the students level.

2. Construct a herringbone outline with the $5 \mathrm{~W}+\mathrm{H}$ (Who? When? Where? Why? What? How?) and the main idea.

3. Students read, brainstorm and write important information about the story in their notebook.

4. After discussion, the students write answers on the Herringbone outline.

5. Students discuss answers $(5 \mathrm{~W}+\mathrm{H}+$ main idea $)$.

6. The herringbone outline is used for the revision of the story.

b. Preparing Instructional Materials and Media

The English materials in this study were being constructed in line with the current curriculum. Narrative was the text types chosen to be taught. The following were competences in teaching reading narrative in junior high school, particularly the eighth grade which is in line with School Based Curriculum (KTSP). One of the standard competence was understanding the meanings of short functional texts and essays in the form of narrative to interact with the environment. This standard was broken down into several basic competences as follows. 
1. Reading loud and meaningful of short functional texts and essays in the forms of recount and narrative with acceptable pronunciation, stress, and intonation relating to the environment.

2. Responding the meanings of short functional texts accurately, fluently, and acceptable relating to the environment.

3. Responding the meanings and rhetorical steps in simple short essays accurately, fluently, and acceptable relating to the environment in the forms of narrative.

It can be concluded that the aim of teaching reading a narrative text is that the students should be able to respond to the meaning and rhetorical steps of a narrative text. Responding to the meaning means that they should be able to determine the main ideas, general ideas, and the content of the text. Meanwhile, responding rhetorical steps means that the students should be able to determine all the language features of narrative text.

According to Keir (2009), the language features of narrative text are as follows:

a. Use of word chains to build topic information.

b. Extensive use of nouns, adjectives, verbs, and adverbs to enhance the plot, setting, and characters.

c. Use adjective to build noun groups.

d. Use time connectives to sequence events.

e. Use thinking and saying verbs to show how characters are saying, feeling, and thinking.

The instructional materials employed in this study were a narrative text entitled "White Snow" as a model text, and two other texts entitled "Bawang Merah and Bawang Putih" and "Tangkuban Perahu". The students' worksheet containing herringbone diagram was also prepared. 


\section{SNOW WHITE}

\section{Orientation}

Once upon a time there lived a little girl named Snow White. She lived with her Aunt and Uncle because her parents were dead.

\section{Complication}

One day she heard her Uncle and Aunt talking about leaving Snow White in the castle because they both wanted to go to America and they didn't have enough money to take Snow White. Snow White did not want her Uncle and Aunt to do this so she decided it would be best if she ran away. The next morning she ran away from home when her Aunt and Uncle were having breakfast. She ran away into the woods.

Then she saw this little cottage. She knocked but no one answered so she went inside and fell asleep.

Meanwhile, the seven dwarfs were coming home from work. They went inside. There they found Snow White sleeping. Then Snow White woke up. She saw the dwarfs. The dwarfs said, "what is your name?" Snow White said, "My name is Snow White."

\section{Resolution}

Doc, one of the dwarfs, said, "If you wish, you may live here with us." Snow White said, "Oh could I? Thank you." Then Snow White told the dwarfs the whole story, and Snow White and the 7 dwarfs lived happily ever after.

\section{Figure 2.}

\section{The Model of Narrative Text}



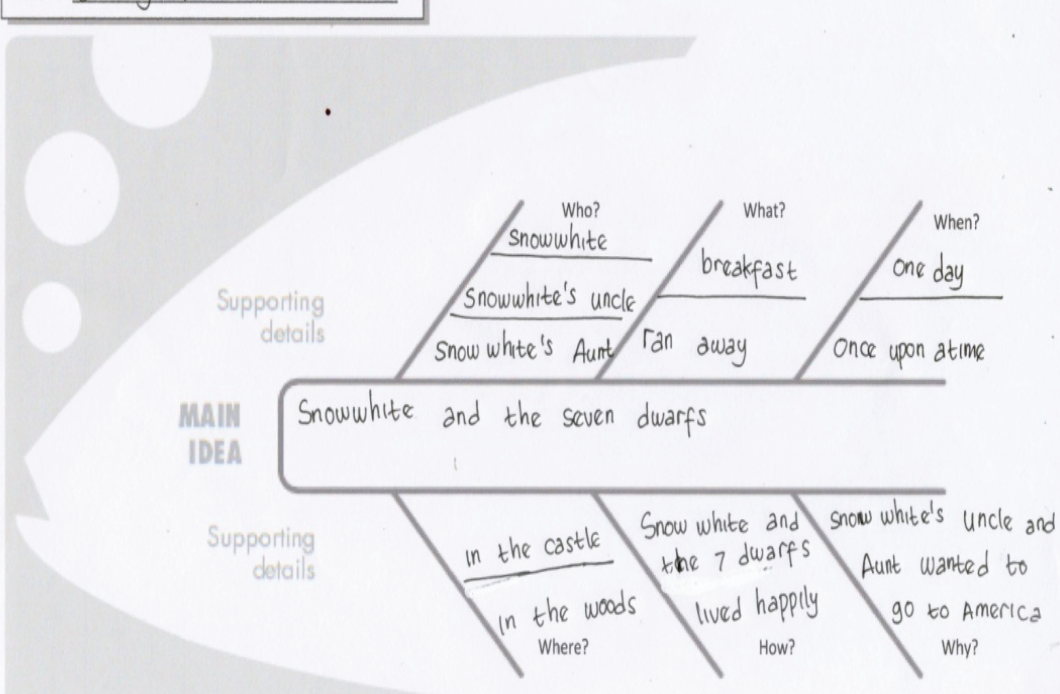

Figure 3.

\section{A Model of Herringbone Diagram}

c. Preparing the Criteria of Success

To determine whether the program is successful or not, there must be an evaluation. The criteria of success were designed to assess the students' ability in comprehending the narrative text given. This study would be considered successful if at least $80 \%$ of the students' reading scores get minimum score of 75 . 


\section{Implementing the Action}

There were two cycles had been implemented in this study. The first cycle was conducted in two meetings in which each meeting was lasted for 90 minutes. The second cycle was conducted in two meetings as well.

In this study, Herringbone Technique is a technique in which the students work in pairs or triads. The teacher poses a narrative text and the students read that narrative text. After reading, the groups complete the Herringbone diagram by discussing the text, considering possible answers to the questions on the Herringbone, and deciding cooperatively upon the answer that seems best to them. When the groups have completed their tasks, the teacher assembles the entire class so that the groups can share their decisions and the reasons for them, with each other.

\section{Observing the action}

During this phase, any data relating to the objective of this study in which herringbone technique was implemented to improve students' reading skill were observed. The observation focused on students' activities and improvements while the herringbone technique was applied

\section{Reflecting}

The last step is reflecting, in this step all data taken from observation and the result test of the students were analyzed and compared to the criteria of success to make reflection whether the herringbone technique implemented was appropriate and worked effectively to solve the problem corresponding to improve the students' skill in reading narrative text.

\section{Findings And Discussions}

This study was managed in two cycles. The first cycles was conducted in two meetings and the second cycle was carried out in two meetings as well. The implementation of action plan and research findings was presented in each cycle. 


\section{Cycle 1}

Cycle 1 conducted in two meetings, on May $10^{\text {th }} 2014$ and on May $11^{\text {th }} 2014$. The first meeting focused on introducing the herringbone technique. The scenario was as follows. The teacher asked the students to have a pair-work. The teacher then distributed each pair-work a narrative text and a work sheet containing a herringbone diagram. Every member of pair-work read the narrative text individually. However, they must discuss with their pair-work when they answered the question on a work sheet. The material used as a model was the story of "Snow White".

The second meeting focused on review of understanding the content of the narrative text and doing reading test. The scenario was as follows. After checking the students' attendance, the teacher gave the simple question about the learning reading by using herringbone technique in the past meeting. Then, the researcher gave them the reading test and answer sheet and asked students answer it by themselves. The reading test was about the story entitled "Bawang Merah and Bawang Putih". 


\section{Lembar Kerja Siswa}

Read the text given and answer the following question on the herringbone diagram!

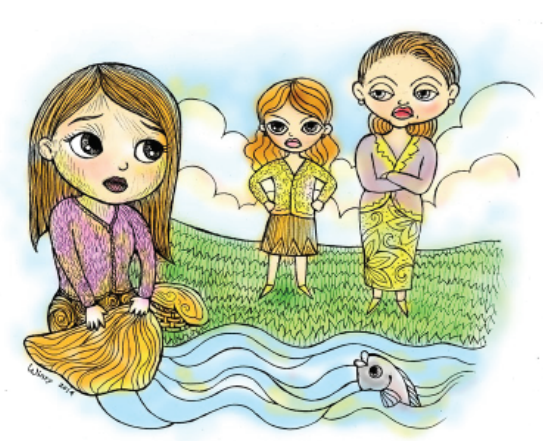

Once upon a time, There were a girl named Bawang Putih, she lived with her step mother and her step sister named Bawang Merah. Bawang Putih's life was sad. Her step mother and her step sister treated Bawang Putih badly and always asked her to do all the household chores.

One morning, Bawang Putih was washing some clothes in a river. Accidentlly, her mother's clothes fell down to the river. Finally, she met an old woman. The old woman returned the clothes. She also gave Bawang Putih a small pumpkin and a big pumpkin. At home, Bawang Merah looked at the pumpkins, and she took a big pumpkin. Bawang Putih opened the small pumpkin and found jewelleries inside her pumpkin. Then, Bawang -

Finally both of them realized their mistakes. They apologized to Bawang Putih and she forgave them.

Figure 4.

The Narrative Text given in Cycle 1

The result of the implementation of Herringbone technique in cycle 1 was unsatisfactory. This study would be considered successful if at least $80 \%$ of the students' reading scores get minimum score of 75 . However, there was 8 out of 16 students could not pass the 
minimum passing score. There was only $66.7 \%$ of students who could achieve it. The average class score was 74.4 from this cycle. It meant that this cycle was not successful yet. Therefore, this study continued to the next cycle.

There were some problem faced in applying herringbone technique in this cycle that must be dealt of. The first problem was there were some students that still did not give attention to the teacher's explanation. They were still busy with their own activity. Secondly, there were still many students who did not do the test completely. The majority of the students only did some numbers, and waited for the teacher to help them in answering the question.

In the next cycle, there were some revision made on the treatment to make it better. To create an interesting activity in the class, the teacher gave a pink heart point as a reward to the student who can answer the question faster and correctly. It was hoped that the students would be motivated to compete with their friend to get a reward by collecting much pink heart point, so it made them more enthusiastic and got good achievement. The second, the teacher gave a clear explanation about activities that had to do by the students in teaching learning process. Ultimately, it make the activity in teaching learning be able to be controlled.

\section{Cycle 2}

Cycle 2 conducted in two meetings, on May $17^{\text {th }} 2014$ and on May $18^{\text {th }} 2014$. The implementation of Herringbone techniques in this cycle was similar to the implementation in cycle I. The difference was only in giving the pink heart for the student who was able to answer the question faster and correctly. The first meeting focused on practicing the use of the herringbone technique. The scenario was as follows. The students were divided into groups that consisted of two members. The teacher gave the students narrative text and work sheet. Every member read the narrative text individually and when they answered the question on herringbone diagram, they should discuss it with their group. The researcher asked the students to demonstrate the result of their discussion. The researcher gave a pink heart to anyone who can answer the question faster and corretly. 
The second meeting focused on review of understanding the content of the narrative text and doing the reading test. The scenario was as follows. After checking the students' attendance, the teacher gave the simple question about the learning reading by using herringbone technique in the past meeting. Then, the researcher gave them the reading test and answer sheet and asked students answer it by themselves. The reading test was about the story entitled "Sangkuriang".

\section{Lembar Kerja Siswa}

Read the text given and answer the following question on the berringbone diagram!

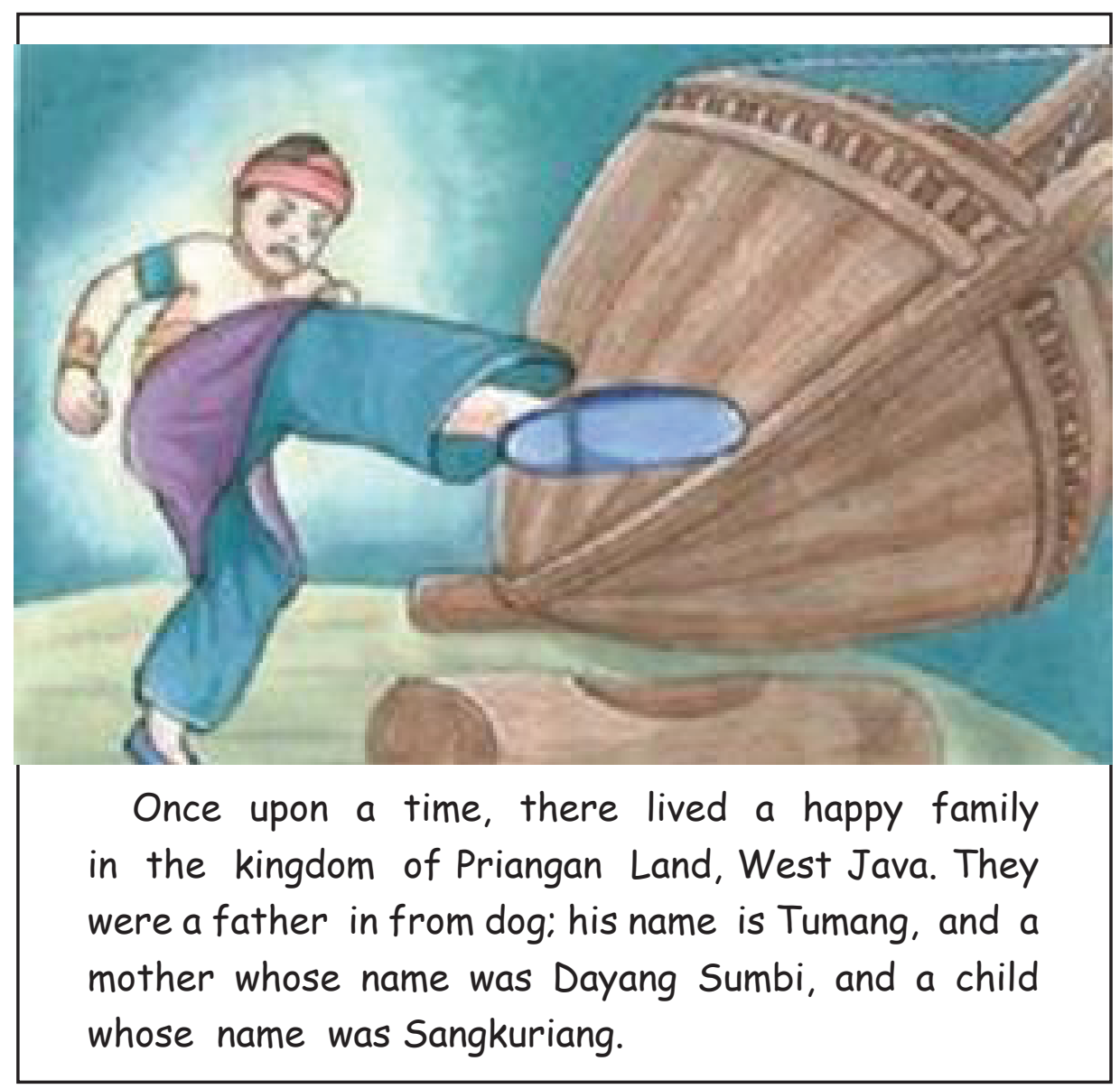


One day, Dayang Sumbi asked her son to go hunting a deer with his lovely dog, Tumang. After hunting all day, Sangkuriang began worried because he hunted no deer. Then he thought to shot his own dog. Then he took the dog liver and carried home. Soon, Dayang Sumbi found out that it was not deer liver but Tumang's liver. She was very angry and beat Sangkuriang's head with wooden spoon. Sangkuriang got scared and then he ran away from their home.

Years went by; Sangkuriang had travelled to many places and finally met a beautiful woman and felt in love with her, she is Dayang Sumbi. When they were having a date in front of her house, she caressed Sangkuriang hair tenderly. Then, she found a scar on his head. She asked Sangkuring about the scar. He said that her mother beat him because he killed Tumang. Dayang Sumbi was very surprised and said, "You are my son! It's possible for me to fall in love with my son". Sangkuriang kept unbelievable in Dayang Sumbi and he wanted to marry her. Dayang Sumbi accepted it under one condition. Sangkuriang had to create a lake and a boot only in a night. Sangkuriang agreed it.

Before the work finished, Dayang Sumbi vanished. Sangkuriang failed to marry her. Sangkuriang was very angry and he kicked the boot. The boat fell down and it became a mountain of "Tangkuban Perahu".

Figure 5. The Narrative Text given in Cycle 2 
Interested in reading narrative text using herringbone technique.Learning activities become more alive and had more variation. The students were motivated to compete with their friend because they want to get a reward by collecting much pink heart, so it made them more enthusiastic to get good achievement. The student's socialization feeling also grew up better.

In cycle 2, all the students (100\% of the students) could achieve the minimum level prescribed for the criteria of success. The result was increasing $33.3 \%$ compared to the result of cycle $1(66.7 \%)$. The average class score was also increasing from 74.4 in cycle 1 to 84.4 in cycle 2.It could be inferred that the implementation of Herringbone technique in Cycle 2 was successful.

Based on the result from Cycle 2, it could be concluded that the herringbone technique applied for the eighth grade students of MTs Al-Fatah Badas was qualified to be able to improve the students' achievement in reading narrative text. The result of this study seems to agree with whatprevious research conducted by Anggraeni (2013) under the tittle the effectiveness of Herringbone Technique in teaching reading narrative text. Anggraeni's research was an experimental research conducted at the eighth grade students at SMP Negri 1 Grobogan in the academic year of $2012 / 2013$. The result of the study revealed that Herringbone Technique provides an effective study when it was applied to reading material.

It also matches with the result of a study conducted by Saputra (2012) which reveals the positive effect of the implementation of Herringbone Technique toward students' reading comprehension for the tenth grade at SMK Negeri 1 Lubuk Sikaping Sumatra Barat. 


\section{Conclusion}

In light of the research findings and discussion, it can be concluded that the implementation of Herringbone technique to overcome the students' problem in reading comprehension is successful. The students get benefit from modeling the use of this graphic organizer on a chart paper. In implementing the Herringbone technique, students are encouraged to organize and classify the information while they are reading. Herringbone Technique as one of graphic organizer used for establishing supporting details for a main idea is an effective tool to improve the students' comprehension.

From the observation in cycle 1, it was found that the students were interested in reading narrative text using herringbone technique; even though, there were still some students who could not achieve the minimum passing score. There were 8 out of 16 students (66.7\%) who could not pass the criteria prescribed. Therefore, this study continued to the next cycle.

In cycle 2, all the students (100\% of the students) could achieve the minimum level prescribed for the criteria of success. The result was increasing $33.3 \%$ compared to the result of cycle $1(66.7 \%)$. The average class score was also increasing from 74.4 in cycle 1 to 84.4 in cycle 2 . It could be inferred that Herringbone technique applied for the eighth grade students of MTs Al-Fatah Badas was qualified to be able to improve the students' achievement in reading narrative text.

\section{References}

Anderson, M and Anderson, K. 1997. The Type in English 3. National Library of Australia: Macmilan.

Anggraeni, V. D. 2013. The Effectiveness of Herringbone Technique in Teaching Reading Narrative Text: an experimental re- 
search at the eighth grade students at SMP Negri 1 Grobogan in The Academic Year of 2012/2013. Semarang: IKIP Semarang.

Balajthy, E. \& Sally Lipa-Wade. 2003. Struggling Readers:

Assesment and Instruction in Grades K-6. New York:

Guilford.

Edwards, P. 2003. Literacy Techniques: for Teacher and Parents ( $3^{\text {rd }}$ Edition). New York: Barrons Educational Series.

Gallant, J.A. 2008. New York State Grade 3 Elementary-Level English Language Arts Test. New York:Barrons Educational Series Inc.

Harmer, J. 1998. How to Teach English. Harlow: Addison Wesky Longman Limited.

Keir, J. 2009. Imaginative Narrative: Perfect the Art of Writing Stories. Greenwood: Ready-Ed Publications.

Kemmis \& Mc Taggart. 1998. The Action Research Planner. Geelong: Deakin University Press.

Koshy, V. 2005. Action Research for Improving Practice. London: Paul Chapman Publishing.

Kristiyani, C. 2008. "Promoting Higher Order Thinking in Reading Class Using Students' Responses to Texts". Proceeding of $6^{\text {th }}$ Asia TEFL International Conference, Bali. 1-3 Agustus, 2008.

Mcknight, K. S. 2010. Teacher's Big Book of Graphic Organizer:100 Reproducible Organizers That Help Kids with Reading, Writing, and the Content Areas. San Fransisco: Jossey-Bass. 
Saputra, B. 2012. The Effect of Herringbone Technique Toward Students' Comprehension for The Tenth Grade At SMK Negeri 1 Lubuk Sikaping Sumatra Barat. Lubuk:STKIP PGRI Sumatra Barat. 